\title{
A Review of Literature on the Associations among Employee Empowerment, Work Engagement and Employee Performance
}

\author{
Rand Al-Dmour ${ }^{1}$, Omayma Yassine ${ }^{2} \&$ Ra'ed Masa'deh ${ }^{3}$ \\ ${ }^{1}$ Department of Management Information Systems, School of Business, The University of Jordan, Amman, \\ Jordan \\ ${ }^{2}$ Department of Business Management, School of Business, The University of Jordan, Amman, Jordan \\ ${ }^{3}$ Department of Management Information Systems, School of Business, The University of Jordan, Amman, \\ Jordan \\ Correspondence: Rand Al-Dmour, Department of Management Information Systems, School of Business, The \\ University of Jordan, Amman, Jordan. E-mail: rand.aldmour@ju.edu.jo
}

Received: April 16, 2018 Accepted: September 20, 2018 Online Published: October 29, 2018

doi:10.5539/mas.v12n11p313 URL: https://doi.org/10.5539/mas.v12n11p313

\begin{abstract}
This paper is concerned with reviewing the concepts of employee empowerment, work engagement, and workforce performance. A historical overview of employee empowerment is addressed at the beginning to provide the reader with an initial understanding of the concept. Then, work engagement and employee performance concepts are reviewed deeply. Also, the links among employee empowerment, work engagement, and employee (workforce) performance are discussed through theoretical and empirical studies. This study will be useful for both academia and practitioners as to fill the gap of the incomplete causal chains among the three concepts.
\end{abstract}

Keywords: employee empowerment, work engagement, employee performance

\section{Introduction}

Human resources considered as the principal component of any business, plus a key factor to achieve the marketplace successfulness and excellence (Obeidat et al., 2012; Muda et al.,2014). Particularly in the service sector, this is considered as labor-intensive and service-oriented sectors depending on human interaction and retains a perfect and skilled workforce (Kim, 2011). Individuals are the worthiest assets that differentiate two businesses (Arunkumar\&Renugadevi, 2013); according to Tetik (2016) they are sources of knowledge and abilities, which cannot be imitated by competitors if they engaged properly. Contrariwise of the technology, products and processes are easily followed by competitors (Elnaga\& Imran, 2014). Employee engagement is essential where the positive emotional connections appear towards the work \& towards the organization's goals and its values (Anitha, 2014; Dajani, 2015; Al-dalahmeh et al., 2018). So, managers strive to maximize their human capitals through improving the engagement level especially in the hospitality industry, which depends on the performance of their workforce by presenting the best guest service quality (Al Azmi et al., 2012; Han, 2015; Abualoush et al., 2018a).

Due to intense business competition and immense challenges, employees are under pressure to obtain new skills and to perform a variety of tasks in their workplace (Suliman, 2001; Kateb et al., 2015). Employees' high performance is considered dispensable but creative performance is a challenging outcome and is what both people/organizations are in search for (Çağlar, 2012). Employees' performance is an essential topic not just in achieving theorganizationalgoals andobjectives but maintaining a competitive advantage over other market players(Yilmaz, 2015). Anenterprises' success mostly relies on the performance of theindividuals. Thus, outstanding performance makes organizations' success in every industry (Heetal., 2014).

Empowerment of employee at the workplace is often a misunderstood concept. Lots of organizations and managers believe that they understand the term of empowerment andare familiar with, while only a few actually do and still, fewer actually put it into the exercise in the workplace (Yaghoobi et al., 2011; Rana \& Singh, 2016).Some managers do not recognize the significance of the employee empowerment effect on theemployee performancelevel (Elnaga\& Imran, 2014), and superiorly believe that empowering subordinates will diminish 
their authority and control on employees (Rehman et al., 2015).This research aims at investigating the literature among employee empowerment influence on sales and marketing workforce performance through the mediating function of work engagement.This is by employing the social exchange theory (SET). Based on SET, when the employee is given the authority to make decisions and take action with freedom and independence, they feel sense of obligation to repay the establishment of which they work for, by showing engaged behavior which in parallel affects the level of employee performance at work environment (Saks, 2006; Nawazet al., 2014).

\section{Literature Review}

\subsection{Employee Empowerment}

When employee happens to make statements like, "I am sorry but it's not me who set the rule" or "Imust consult my manger but I can't find him" this is a clear sign of the absence of empowerment in lots of establishments, in other word employees are disempowered at their workplace (Pelitet al., 2011, p. 796).In the compact Oxford dictionary (2018), the term "empowerment" refers to "providing power to someone to do something". However, power has several meanings: in a legal sense means authority, so that empowerment means authorization. Power can describe the capacity as in self-efficacy definition of Conger \& Kanungo (1988). Power a mean energy, thus, to empower individuals can also mean to energize individuals (Thomas \& Velthouse, 1990).

Today's more than $70 \%$ of organizations have adopted and accomplish more or fewer forms of employees' initiatives in its workplace (Tetik, 2016). Employee empowerment is considered as part of a broader concept named "employee involvement" which also includes "participative management", "job enrichment"and "industrial democracy" (Shahril et al., 2013; Ameer et al., 2014). Encouraging employees' participation goes back to the 1960s when the manager understood the benefits that can be obtained from sharing power with their subordinates and gives them the authority and freedom to control their work -related activity (Cacioppe, 1998).

The procedure of enabling individuals to think, behave, and act to make decisions about their work independently is called the empowerment (Han, 2015), and feel that they are part of an institution and valuable not just follower (Kok et al, 2011). Employee Empowerment is replacing the concurrent control by managers as the holder of power (bureaucratic/classical management); via the direct supervision of self-employee control (Guzel et al., 2008). With empowerment power is shared, all employees participate in the decision-making process, and not punished for their mistakes but rewarded for trying (Abraiz et al., 2012). Leaders who empower their individuals enable organizations to deal successfully with market turbulence, challenges and foreseen demands of the outlook (Abdissa \& Fitwi, 2016).

Recently, employee empowerment has become a part of the global business philosophy (Rehman et al., 2015). Due to globalization, there is a dire need for empowerment that makes employees in a position of making accurate and quick decisions and takes the initiative for reacting speedily and timely to the job environment pressures (Orgambídez-Ramos \& Berrego-Alés, 2014; AlHarrasi\& AL-Lozi, 2015; AlHrassi et al., 2016; Obeidat et al., 2017).Also empowered employee became more proactive and enthusiastic to provide excellent service quality for creating customer satisfaction (Shahril et al., 2013). In other hand, the employee must not only be empowered to make appropriate decisions but be accountable for the consequences of their decisions for the reduction of irresponsible behavior at work (Scarnati \& Scarnati, 2002).

Empowerment practices are often approved by several services organizations, with the hope of overcoming worker dissatisfaction and poor service quality in the health segment (Rehman et al., 2015), education sector (Hanaysha\& Tahir, 2016), service sector (Abraiz et al., 2012), and financial sectors (Ukil, 2016). Employee empowerment found that has a significant influence in contributing to the delivery of service quality and in enhancing the level of job satisfaction (Ukil, 2016). So, manager must maintain and reinforce the employee empowerment high level due its importance to work outcomes (Rehman et al., 2015). This can be done through decentralizing the decision-making process, where the staff makes timely decisions (Akhtar et al., 2016).

In hotels segment, empowering front-line employees have positive influence to their satisfaction, increase the efficiency of the operations \& enhance service provided as several studies have revealed (Melhem, 2004; Ayupp\& Chung, 2010; Kim, 2011; Pelitet al., 2011; Al-Ababneh et al., 2017).On the contrary, Shahrilet al.(2013) study did not support suggestions in which higher level of empowerment should result in higher level of job satisfaction through front-line staff in the hospitality industry, but empowerment plays a crucial role in succeeding services, guarantees and motivates the employees.

\subsubsection{Employee Empowerment Obstacles}

In the workplace setting, management faces many barriers and difficulties when trying to empower their members. The obstacles that could prevent organizations from becoming empowered firms can be classified as 
follows:

\subsubsection{Employee Obstacles}

- Employees consider empowerment an additional responsibility, which requires additional efforts (Kim, 2011).

- They are reluctant in making responsible decisions as they don't want to be blamed for any mistakes arise from any decision (Ambad \& Bahron, 2012).

- $\quad$ Employees are fearful to make decisions without referring to their managers stems from fear of making mistakes\& getting punished (Azeem \& Sayed, 2010).

- Employees are not willing yet (Ameer et al., 2014) and not interested in empowerment initiative (Elnaga\& Imran, 2014).

- Employees' resistance to alteration (Rehmanet al., 2015).

\subsubsection{Manager Obstacles}

- Managers are not accepting to share their power with inferiors, because they fear of losing the control over employees (Kim, 2011).

- Managers do not trust employees, because sharing information means leaking ideas and knowledge to rivals (Ambad \& Bahron, 2012).

- Managers are not convinced that their inferiors can make decisions of which administrators can benefit from without deviations from goals (Azeem \& Sayed, 2010).

- Managers'resistance to change (Rehmanet al., 2015).

\subsubsection{Employee Empowerment Requirements}

Employee empowerment is not sufficient to ensure the desired outcomes, because there are some critical variables that should be taken intoconsideration in order to have an effective empowerment organization experience:

- The manager should grant their worker the proper materials and training required to make a considerable \& correct decision, also enhance their skills and their understanding of the overall business scope such as dealing with the client complaints and providing good service recovery (Guzel et al., 2008).

- Building mutual trust between subordinates and managers for the reduction of fear and encouraging decision-making process in the work (Kim, 2011;Pelit et al., 2011).

- A Careful section of employees, identification of common objectives, employee support, accountability and open connection, as well as build "win-win" rather than "win-lose" attitudes (Songanet al., 2016).

- Empowerment should be treated as a part of the organizational culture (Shannak \& Obeidat, 2012; Hanaysha \&Tahir,2016) which demands change in corporate culture, where everyone must adopt new principles and values, particularly senior managers how are responsible for empowerment implementation (Abraiz et al., 2012).

\subsubsection{Empowerment Benefits and Disempowerment Problems}

The right empowerment adoption brings to company various advantages, like saving the employing cost and training by increasing employee retention (Kim, 2011; Mikkawi \& Al-Lozi, 2017), especially in the hotel sector, which retains the quite skilled workforce and suffers from the high turnover rate (Zainol et al., 2016). Also, empowered people have a positive sense of purpose in their task, and self-motivated to involve in continuous improvement at the workplace (Rehman et al., 2015; Songan et al., 2016). By delegating of power to subordinates, organizations avoid time-consuming for superiors to make decisions that are less important or routine ones, and let themconcentrate more on strategic organizational issues that are crucial for organization's competitiveness (Ayupp\& Chung 2010; Hee et al, 2014). For the employees, they can consider empowerment as an intrinsic reward from their job, and proud of their work activities which gave them the opportunity to pursue creativity, flexibility, and autonomy at work (Cacioppe, 1998). Furthermore, with empowerment conflicts in the workplace become less, because the worker is involved in the decision-making role and participate their opinions with the managers (Elnaga\& Imran, 2014), which in result break the barriers and foster the trust among members and management (Tajuddin, 2013). Table (1) shows the empowerment benefits and problems that can occur in the absence of empowerment in the hospitality industry. 
Table 1. Empowerment and disempowerment in hospitality operations(Adopted from Lashley, 1995)

\begin{tabular}{|c|c|}
\hline Benefits of Empowerment & Problems of Disempowerment \\
\hline $\begin{array}{ll}- & \text { More responsive service. } \\
\text { - } & \text { Quick dealing with Complaints. } \\
\text { - } & \text { Create customer satisfaction. } \\
\text { - } & \text { More repeated business. } \\
\text { - } & \text { Well-motivated staff. } \\
\text { - } & \text { Improved labor stability. } \\
\text { - } & \text { Increased productivity. } \\
\text { - } & \text { Lower labor costs. } \\
- & \text { High quality. } \\
\text { - } & \text { High profits. }\end{array}$ & $\begin{array}{ll}\text { - } & \text { Limited authority to meet service needs. } \\
\text { - } & \text { Slowly dealing with complaints from } \\
\text { senior manager. } \\
\text { - }\end{array}$ \\
\hline
\end{tabular}

\subsubsection{Factors Effect on Employee Empowerment Perceptions}

In the hotel enterprises, there are three main factors that can have an impact on employee empowerment perceptions (Çavuşet al., 2015):

- Hotel Star: The individual working in five-star hotels feel more empowered than the ones working in four-star hotels because five-star hotels are more qualified in an organizational and corporate sense.

- Hotels Geography: The employee working in city hotels has a higher empowerment perception than the employee working in seasonal hotels (summer palace).

- Managerial Level: Individuals working at the top level in the company feel moreempowered than the ones working at lower organizational level.

\subsubsection{Employee Empowerment Steps}

Pelit et al.(2011) summarized the empowerment process at hotels establishment in two-steps: first; The manager should discuss with their members the content and goals of the empowerment activities that are going to be practiced and implemented in the department they are responsible for. Second; Provide help, support and the training needed to become familiar with these activities, increase acceptance level toward empowerment practices, plus eliminate or minimize their resistance to change. The manager provides benefits for achieving the desired outcomes from these empowerment activities by a detailed examination of employee competence.

According to Mohammadian \& Amirkabari (2014), employee empowerment can be presented in three phases:

a) Information sharing: Starts with entrusting in the organization \& breaking down the traditional hierarchical and thinking which results in obtaining the employees' responsibilities.

b) Autonomy and independence in the whole organization.

c) Changing the hierarchies with self-conducted teams: The favors of self-conducted teams are providing job satisfaction, attitude change and building a better relationship between the employee and manager.

\subsubsection{Employee Empowerment Perspectives}

After an in-depth study of literature, two main pointed out perspectives dealing with factors that give birth to empowerment (Çağlar, 2012); The internal factor or psychological empowerment (micro perspectives), and external factors or structural empowerment (macro perspectives). At thefirst glance, structural and psychological empowerment might be seen quite similar, but important differences between the conceptsexist. The perceptions of psychological empowerment based on external factors that surround and encounter individuals, whereas structural empowerment is the presence or absence of empowering conditions at work. Psychological empowerment is about reactions to these structural empowermentsituations, in other words, is a logical structural empowerment outcomes (Laschinger et al., 2001; Laschinger et al., 2003; Khalayleh et al., 2017).

The current study considers the structural and psychological empowerment as independent variables.

\subsubsection{Structural Empowerment}

Structural empowerment or organizational empowerment relies on increasing individuals' involvement in thedecisions making process, by giving them the authority and freedom at their workplace (Çavuşet al., 2015). This is also deemed as an action that the organization takes to share authority and power with its members to take decisions (Tetik, 2016), by giving the subordinate withthe specific guidelines to the extent they can make 
decisions and take action without getting the permission from their supervisors (Cacioppe, 1998).

Al-Ababneh et al. (2017) identify empowerment from a structural perspective as "the extent to which the members believe that he/she has been given the autonomy and authority to function independently deriving from aspect such as; training, rewarding system and management style". O'Brien (2010) also described the empowerment as the structure of opportunities and structure of power that enable the worker to feel empowered, and create positive attribute and outcomes such as the reduction of the level of burnout that the workers (nurses) feel towards work.

Structural empowerment represents a powerful approach to create a workplace that attracts and retain the individuals to organizations because the employee has the chance to increase his/her competence, gain new skills and rewarded for their contribution to the organizational objectives (Ahadi\&Suandi,2014). Structural empowerment originated at the upper management level and is passed down to the employee which is the ground agreed upon view of the empowerment initiation process (Appelbaum et al., 2014). According to Ameeret al. (2014) employee at low levels of the organizational ladder can be structurally empowered if they have access to opportunity, information, resources, and support.

Kanter's (1993) theory of structural power of organizations provides a useful explanatory framework for studying job environment setting; on the employee perceptions of the real conditions in the workplace, plus eliminating the workplace conditions that can conduct employee feel powerlessness. Because the individual's reaction to the stand structured in this way that employee feels empowered, he/she is more likely to accomplish the job and satisfied with it.Kanter (1993) defines empowerment from the leader role perspective in empowering individuals, this means that manager adopts the coaching style rather than controlling one assists individuals to solve the problem through sharing power with them. In her opinion, empowerment results from decentralization, flattering hierarchy and increase worker participation.

Based on Kanter (1993) structural theory of power, "power" is determined as the ability to get things achieved. When power is "on" employees have access to the line of information, support, resources and opportunity to develop and learn, but when power is "off"the effective work is impossible also affects the feel empowered (Sarmiento et al., 2004). Hence, workers are empowered when they perceive that their job provides them with the opportunity to learn, advancement, and grow, plus access them to the line of power which includes: resources, support, and information (Kanter, 1993; O'Brien, 2010).Resources refer to the necessary money, time, and equipment to perform work (Çavuş\& Demir, 2010; O'Brien, 2010). Supportbe relevant to receiving guidance and feedback from supervisors, peers and subordinates (O'Brien, 2010; Horwitz \& Horwitz,2017), while information relates to the knowledge of the policies, data, and goals of the organization (Çavuş \& Demir, 2010; O'Brien, 2010).

Access to these organizational structures (line of opportunity and power) that permit employees to do their work in meaning fully way is facilitated by the formal and informal power degree that an individual could have in the organization (Laschinger et al., 2004). Formal poweris about job definition; flexibility, visibility, and relevance that employees have in their job and are central to the overall organization purpose (Sarmiento et al., 2004; Horwitz \&Horwitz,2017). Whereas Informal power is connections outside and inside organizations, alliances with supervisors, subordinate, and peers (Sarmiento et al., 2004;Horwitz\& Horwitz,2017).

Kanter theory of structural empowerment is widely adopted by nurses' segment employees in the health organizations in the west. It is a predictor for increasing job satisfaction and decreasing the level of burnout (Sarmiento et al., 2004; O'Brien, 2010), reducing job strain (Laschinger et al., 2001), enhancing quality patient care (Regan \& Rodriguez, 2011), in addition, boost effective commitment toward organization goals andplacing the culture of patient safety (Horwitz \&Horwitz, 2017). Structural empowerment was implemented also in the education sector as an antecedent of organizational commitment and job satisfaction (Orgambídez-Ramos \& Berrego-Alés, 2014; Khoshhal \& Keshtegar, 2016).

The researchers define the structural empowerment as setting up work conditions where members have the availability to easily gain the resources and information needed for a considerable and fruitful decision-making. Thus, managers are present for supporting, coaching and grants their members the opportunity to progress and develop.

The conceptual framework that guided this research relay on structural empowerment as described by the Kanter theory of structural power (1993).According to Cacioppe (1998), structural empowerment can be implemented truly in hotels based on the following stages:

1. Create management commitment: Facilitate and lead empowerment process. 
2. Building a support system: Any establishment should have an environment that assists the empowerment process by:

- Development the directions of the empowerment in order to set boundaries and limit the decision-making actions of employees.

- Empowerment team suggestions form: To obtain ideas and suggestions out of the employee for improving guest service.

- Rewarding employee who recognizes empowered behaviors, also organization must make information available for all worker, because when employee share information they can focus on achieving the organization's mission.

3. Empowerment Training: To gain employee commitment and provide the necessary skills and knowledge for them, such as problem-solving skills to enable individuals acting in an empowering manner.

\subsubsection{Psychological Empowerment}

Until the late 1980 s, the researcher was concentrated on external factors that empower the employee. Conger \& Kanungo (1988) were the first pioneers how focus on the psychological experience of empowerment. They observed the empowerment from the personal perspectives, which refers to the power of individuals to persuade them self or having "self-empowered". The researchers argue that management practices are only set of conditions and those practices may empower employees, but will not necessarily do that. In other words, the concept of administrative implementation deals with the administration attempts to provide the conditions necessary for empowerment. So, this is not sufficient, the employee managerial implementations perceptions are of great significance, which composes psychological aspect of empowerment (Pelit et al., 2011).

Conger \& Kanungo (1988) define empowerment as the process of boosting the "self-efficacy" feeling among organizational members. Then, Thomas \& Velthous (1990) extended the approach of Conger \& Kanungo (1988); determine four dimensions of task cognitions that affect intrinsic task motivation, namely: meaningfulness, competence (which is equivalent to Conger \& Kanungo's self-efficacy), impact and choice (self-determination). Thomas \& Velthouse (1990), Conger \& Kanungo (1988) define empowerment based on the expectancy theory of motivation also known as valence -instrumentality- expectancy theory (VIE) theory, developed by Victor Vroom (1964),this theory assumes that individuals are going to select the behavior that they perceive will bring valued and significant outcomes, this cognitive process evaluates the motivational force (MF) of different behavioral choices based on the person perceived view of an outcome. The motivational force can be summarized by the following equations:

$$
M F=\operatorname{Expectancy}(E) * \text { Instrumentality }(I) * \operatorname{valence}(V)
$$

- $\quad$ Expectancy $(\mathrm{E} \rightarrow \mathrm{P})$ : Known as the E-P linkage, relate to the perceived likelihood that high effort will lead to better performance, is a belief about the future rather than concrete existence in the work environment. So, the manager must encourage and build self-efficacy of their employees, by providing them with the accurate resources, skills, information, and support from their boss, peer, and subordinate, to enhance individuals' expectancy (http://www.leadership-central.com).

- Instrumentality $(\mathrm{P} \rightarrow \mathrm{O}):$ Known as the $\mathrm{P}-\mathrm{O}$ linkage, refers to the individual perception that meets performance expectations, will lead to desired rewards. Some conditions that enhance the instrumentality are having a clear understanding of the relationship between performance and the outcomes, having trust for people who make the decisions on who gets what reward (http://www.leadership-central.com).

- Valence V(s):Is the value of expected rewards to the individual, is directly Related to who they are: their need, goals, and values /preferences (http://www.leadership-central.com).

This theory can help to explain how empowerment can lead to desired behavioral consequences of an employee in the organization (Songan et al.,2016). Using the Thomas \& Velthous (1990) model as a theoretical foundation, Spreitzer (1995) focused on the psychological interpretation that the employees make out of their job conditions. She developed a scale to assess the validation of the four dimensions of psychological empowerment. Spreitzer defines empowerment as "increase intrinsic motivation manifested in four cognitions in task assessment, namely; meaning, impact, competence, self-determination":

- Meaning: Result from the feeling that jobs task is valuable and make differences (Stander \& Rothmann, 2010), fit between the requirement of work and person beliefs, value, and behavior (Spreitzer, 1995; Khera, 2015). 
- Impact: Is the individual's belief and the perception that may affect strategic, operational and organizational outcomes (Çavuş \& Demir, 2010; Kok, 2011).

- Competence: Indicates self-efficacy, and is related to the person's capability and the ability to do the task assigned, or job requirement with skills (Khera, 2015).

- Self-determination: Refers to the autonomy and freedom that ones have at work to make decisions about work methods, pace \&efforts (Spreitzer, 1995; Kok, 2011).

The highest individual "score" in each of these factors indicates the greater sense of empowerment and the lack of any sole dimensions cause a decreasing in the feeling of empowerment level (Spreitzer, 1995). If an employee, for example, believes that he/she has the right job tact's (dimensions of competence) but then perceive that he/she lacks the capability to affects the outcomes (dimensions of impact) there will be a negative effect on the member's empowerment sense (Appelbaum et al., 2014).The individuals are psychologically empowered when he/she feels that the job he/she does is meaningful \& significance (Kahn, 1990), as well as has an impact in shaping and achieving organizational outcomes, and consider themselves as active contributors (O'Brien, 2010). Also, when he/she has confidence on how to perform their tasks, he/she trusts his/her ability and choices, which resulting in satisfaction and positiveness towards the job (Al-Ababneh et al., 2017).

Lots of research reveals the significance of psychological empowerment as predictors to increase the job satisfaction in a various sector, such as; banking sector (Obeidat et al., 2013; Khera, 2015; Abdissa \& Fitwi, 2016), IT industry (Rana \& Singh, 2016), education sector (Schermuly \& Schermuly, 2011) and hotels sector (Pelit et al., 2011; Al-Ababneh et al., 2017). Hence, psychological empowerment has a significant impact on organizational commitment (Ambad \& Bahron, 2012) and HR productivity (Yaghoobi et al, 2011).The conceptual framework that guides the study is founded on psychological empowerment as described by Spreitzer (1995).Empowering employee can take many shapes. There are five empowerment stages psychological construct as determined by Conger \& Kanungo (1988). Phases number 1: determines the circumstances within the workplace that are accountable for the feeling of powerlessness among employees, this leads the manager to the use of empowerment strategies in phase 2 . The adoptions of these strategies are aimed not only at canceling some external factors are capable of powerlessness, but also at providing subordinates with self-efficacy data on phase 3. As a result of receiving such data, subordinates feel empowered in phase 4 , and the behavioral effects of empowerment are noted in phase 5 .

\subsection{Work Engagement}

\subsubsection{Work Engagement Definition and Dimensions}

Nowadays, many organizations are adopting several techniques and change in the way of running their individuals, to enhance their staff engagement level. In general, employee engagement is an emotional connection and positive attitude that one's feel toward his/her work, organizations and its value, and has passion about its goals (Anitha, 2014; Dajani, 2015). Without employee engagement in the workplace, companies cannot survive long in the market (Zainol et al., 2016), because engagement is a prior business driver for organizational success.

The first engagement conceptualizing was realized by Kahn (1990) as "the harnessing of institutional members' selves to their job role...In the engagement, people employ and express themselves physically, cognitively and emotionally during role performance". Kahn (1990) study determines three psychological engagement conditions needed for people to be correctly engaged, and whose absence influenced the personally disengage namely:

- Meaningfulness: Related work elements that can encourage or not encourage engagement in the workplace. It is the return on investment that one's feel in the role performance (Kahn, 1990).

- Safety: Associated with social elements, including manager style, organizational norms that affect personal engagement or disengagement. The employee can show self-fear of negative consequences (Kahn, 1990).

- Availability: A sense of possession of different resources; the physical, emotional and psychological required for role performance (Kahn, 1990).

According to the Kahn (1990), workers were more engaged with situations that provide them with psychological meaningfulness, psychological availability and psychological safety.

Another engagement pattern comes from the "burnout" literature, which views job engagement as the positive opposite of burnout and characterized by energy, involvement, and efficacy, and these are the direct opposite of burnout dimensions (Maslach et al.,2001). They determined six areas of life work lead either to burnout or to engagement, which are: Workload, control, rewards \& recognition, social support\& community and perceived 
fairness \& value. The greater mismatch between the job and the person, the greater likelihood of burnout, conversely the greater match or fit the greater likelihood of engagement.

Kahn's (1990) and Maslach et al. (2001), indicated that the psychological antecedents or conditions responsible for the engagement of the organizational members in the work environment.

Engagement is defined as "positive, fulfilling, work-related state of mind that is characterized by absorption, dedication, vigor"(Schaufeli et al., 2002):

- Vigor: High grade of energy and mental resilience while working, making effort abilities in work \& face work challenge with persistence(Schaufeli et al., 2002; Nawaz et al.,2014).

- Absorption: Happens when people are fully concentrated and immersed in work whereby time flies and one has difficulties in separating oneself from job(Schaufeli et al., 2002; Nawaz et al.,2014).

- Dedication: Is sense significant, pride and enthusiasm that individuals have towards their job (Schaufeli et al.,2002; Nawaz et al.,2014).

Saks (2006) defines engagement as the degree an individual is attentive and absorbed to role performance. This concept has two dimensions (Saks, 2006): work engagement \& organizational engagement, and they are related to distinct constructs. The deviation between them is connected to role identification. Based on Saks (2006) perspective, employees' work role differs from their role in their organization. He defines organizational engagement as private and positive correlation towards their institution. He asserts that the psychological conditions lead to job/organizational engagement, as well as their consequences is not similar. This study leans on work engagement as described by Schaufeliet al. (2002).

\subsubsection{Engagement Requirements and Benefits}

Training and development, leadership and rewards, internal communication, are considered as key determinants of employee engagement among individuals working in hotel establishments (AL-Syaidh et al., 2016;Darawshehet al., 2016; Zainol et al., 2016; Alkandari et al., 2017). In accordance with Saks (2006) and Arunkumar \& Renugadevi (2013): job characteristics, perceived organizational \& supervisor support, rewards \& recognitions, procedural justices and distributive justices are the key antecedents of improving the level of engagement. High degree of individuals engagement in any company can create several benefits for the two; organizations and individuals like: attract the skilled and talented workforce, foster customer loyalty, enhance organizational profitability and performance, stakeholder value (Arunkumar \& Renugadevi, 2013), as well as increasing the level of job satisfaction, organizational attachment and commitment, reduces the intention to resign, and organizational citizenship behavior, because engaged employees don't frequently quit the job (Saks, 2006; Arunkumar \& Renugadevi, 2013).

\subsubsection{Social Exchange Theory}

Social exchange theory (SET) is the most theory used and accepted by recent researchers on the topic of employee engagement, which provides a meaningful and theoretical basis for understanding, plus studying the engagement of individuals in the workplace (Saks, 2006). The (SET) was constructed by Blau (1964) and Emerson (1981). It provides a basis for manager role in creating feelings of employee obligations to reciprocate the organization and showing positive work attitude (Blau, 1964; Masa'deh et al., 2018). While Emerson (1981) defines (SET) as the involvement of two people who provide benefits to each other and contingent upon benefits by others.

People in this theory, are able to make the social decision at their workplace based on the recognized cost and mutual benefit. So, they will be engaged in work actions when there is a fair system in the job (Dajani, 2015) because exchange role usually involves reciprocity or repayment principles, such as the action of one side create and lead to a response by another side (Saks, 2006). For example, when individuals receive economic and social-emotional resources from the organizations they work for, they feel obligated to respond showing the engaged behavior inking of repaying (Arunkumar \& Renugadevi, 2013).

The employees feel obligated to bring themselves more deeply into their role performance as repayment for the resources they receive from their organization, and when the institution's fiats to provide these resources, individuals are more likely for disengaging themselves from their function (Kahn, 1990). Based on (SET)when the employee has given empowerment and training needed, he/she feels a sense of consideration and repays his/her organization by showing engaged behavior which effects on employee performance (Nawaz et al., 2014).

An individual who is granted with high work characteristics such as psychological meaningfulness that provide challenging work use all employee skills and the opportunity to make vital decisions are likely to reciprocate 
with greater work engagement (Kahn,1990; Saks, 2006).

\subsection{Employee Performance}

\subsubsection{Employee Performance Definition and Dimensions}

Work life is a significant part of the employee routine life (Rehman et al., 2015). Where worker does various tasks in the firm (marketing, sales, productions... etc.), all these activities performed by persons are interrelated to the organizational goals. So, employee performance has a direct impact on the output, sales and profits of the organizations (Masa'deh et al., 2008; Hee et al., 2014).In the early 1990s, organizations have commenced conceptualizing performance as a multifaceted construct (Suliman, 2001). Employee performance relays basically on goal achievement made at business (Anitha, 2014; Abualoush et al., 2018b). It indicates financial and nonfinancial added value of employee's contribution to work to the attainment of both, directly and indirectly, organizational goals (Dajani,2015), and the rate of realization of the purpose and activity outcomes level (Tajuddin, 2013). In the other word is about worker achieving results or standards as cited by organizations (Kok, 2011).

Job performance relates to the outcomes quantity and quality of the person's effort and achievement (Rizwan et al., 2014). According to Akhtar et al. (2016), job performance also refers to the standard of outcomes achieved by individuals comparing with their colleagues, and the key to improving the whole organization's performance. Employee performance can be viewed in light of two perspectives: 1) employee perspective, which is the result of a series of behaviors and tasks performed daily. 2) Manager's perspective outcomes are the key factor for work performance appraisals (Yilmaz,2015). Thus, many business directors assess the employee performance on the yearly or quarterly basis to identify and suggest area needed for improvement (Hee et al., 2014). Effectiveness and productivity mainly used by researchers as a synonymous with performance, but actually, they are not similar. Effectiveness refers to the evaluation of the outcomes of performance, and the worker should reward though performance, not effectiveness. Oppositely, productivity is the output ratio to the cost of achieving that output that level of input (Suliman, 2001).

There are two dimensions of the individual's behavior in the job performance: Task performance and contextual performance. The two types contribute to the institutional effectiveness but in a different method. Task performance can be defined as employee's behavior directly related to the producing of goods or service activities that provide indirect support for the institutional core process (Hee et al.,2014)such as the quality and quantity which use task performance criteria to measure employee performance (Kahya, 2007). Contextual performance or organizational citizenship behavior is the effort of employees not related directly to the major task function or compensation system, but still important to increase the firm outcomes effectiveness (Akhtar et al., 2016), such as employee cooperation with the manager and suggesting ideas to improve the institutional process. These are some patterns of contextual performance standards utilized to measure employee performance (Kahya, 2007). According to Tajuddin (2013), the contextual performance is that workers get out of their defined role attitude to additional role behaviors.

\subsubsection{Factors Affecting Employee's Performance}

Performance of employee is influenced by several factors at the workplace, some of them are:

- Long working hours: working for a long time can reduce the efficiency of the employee because continuously working increase the chance of faults. So, the manager should give their individuals some rest time during work, to have a fresh and energetic workforce (Iqbal et al., 2015).

- Training: training has a positive effect on employee's performance, by providing them with the skills and knowledge needed to accomplish the assigned tasks. The person will be confident about his work role comparative to the employee who is not being trained (Iqbal et al., 2015).

- Job stress: workplace stress has negative effects on the employees' job performance, it occurs when the demand exceeds the capacity of an individual which in parallel fails to satisfy the top management. The potential of job stress can arise from three factors: environment, organization, and individual (Muda et al., 2014).

- Communication: communication barriers play a negative role in the employee performance. So, the manager should show the initiatives of improving and giving the opportunities to grow and learn new skills to their employees through the communication process (Al-Syaidh \& Al-Zu'bi, 2014; Muda et al., 2014).

- Motivation: intrinsic or extrinsic motivation forms the major reason for working in life. It refers the desire to do something, conditioned by the ability to fulfill some needs. Motivation increase employee 
self-satisfaction, self-fulfillment and commitment, which ultimately produce a better quality of work, and good performance (Muda et al., 2014).

\section{Employee Empowerment and Employee Performance}

The former researchers have drawn attention to the significant relationship between employees' empowerment and performance (e.g.Kok, 2011; Mehrabani \& Shajari, 2013; Tajuddin, 2013; Hee et al, 2014; Yilmaz, 2015; Sun, 2016; Tetik, 2016).Yilmaz (2015) examined the influence of psychological empowerment on job performance over frontline employee in the hospitality industry. The study showed that the job performance is significantly correlated to the four dimensions of psychological empowerment. Self-determination and impact dimensions of empowerment are more influential than job meaning and employee competence of their influence on job performance. Moreover, there was a significant difference among the demographic variables (gender, age, and work experience) and perceived empowerment, but no significant differences among empowerment level and educational level.

About (89) respondents from (21) automotive companies participate in the conducted research. Kok (2011) examined the impact of four dimensions (impact, meaning, self-determination, competence) of psychological empowerment on employee performance. The result reveals the strong influence of employee empowerment on performance, because when employees feel that they have the independence and freedom to take decision-related to their work-related activities, their performance in the workplace shall improve positively. Several researchers conducted in the manufacturing context reveal the significant effect of employee empowerment from a structural perspective on employee performance level (Tajuddin, 2013; Rajalingam et al., 2015). Rajalingam et al. (2015) evaluated the impact of four empowerment tools: power, knowledge, and rewards, over employee performance with the performance appraisal as mediating role among (200) employees working with industrial Malaysian companies. The results show that the four dimensions of empowerment had influenced both employee performance \& appraisal performance, where appraisal performance mediates the relationship between an employee performance and empowerment.

Mehrabani \& Sahjari (2013) research which was conducted in the University Hospitals in Iran, focused on leadership empowerment, which assures the leader role to empower an employee, including serving others, monitoring others, mentoring others, and coaching others on employee effectiveness including: employee performance and employee satisfaction. The outcomes show that serving and mentoring others has a positive impact on employee satisfaction and performance, but coaching others only had influence on employee performance, while monitoring others did not show relationships with the two dimensions of individual effectiveness. Sun (2016) conducted a research to examine the effect of psychological empowerment on job performance using the mediating function of job satisfaction. The results show that meaning, self-determination, competence and impact (the four dimensions of psychological empowerment) correlate positively with task performance and contextual performance of job performance, indicating that psychological is considered as predictors of work performance. The results also show that employee job satisfaction mediates the relationship between job performance and psychological empowerment.

\section{Employee Empowerment and Work Engagement}

The positive alliance in implementing the employee empowerment program on work engagement in different segments was highlighted by previous researchers (Laschinger et al., 2004; Stander \& Rothmann, 2010; Çağlar, 2012; Nawaz et al., 2014; Ugwuet al.,2014; Nawrin, 2016).

Stander \& Rothmann (2010) examine the relationship between psychological empowerment, employee engagement and job insecurity among employee working in a government \& manufacturing organization. The result reveals that there is a significant relationship between job security, psychological empowerment, and work engagement. On the other hand, the study also showed that job insecurity has effects on the three dimensions of psychological empowerment (competence, meaning, impact) and overwork engagement. Moreover, the four dimensions of psychological empowerment (self-determination, competence, meaning, impact) predict engagement (vigor, dedication, and absorption) of the employee.

Ugwu et al. (2014) investigated the influence of psychological empowerment on the relationship between organizational trust \& work engagement among Nigerian employees working in commercial banks and pharmaceutical firms. The results reveal that the strongest predictor of work engagement is psychological empowerment, followed by organizational trust. Moreover, psychological empowerment moderates the relationship between organizational trust and work engagement. Means that the employee perceives both good organizational trust and great psychological empowerment is going to show a high work engagement 
level.Furthermore, the study found that where an employee grasp's poor organizational trust and great psychological empowerment will show a high level of work engagement than the employee with lower levels of psychological empowerment.

Nawazet al. (2014), conducted a research to examine the relationship among HR practices (training, empowerment) and the workers' creativity via employee engagement as mediator. There were (400) respondents from (110) manufacturing firm in Pakistan. The result showed that when the workers are given the empowerment and training needed, they felt that the organization takes care of them; they also felt as valuable asset, not as followers, and led to a high level of engagement by the employees in the form of repaying to their organization; which in return leads to the creativity of the individuals at work.

While Laschinger et al. (2004) conducted a research on fresh graduate nurses in Canada to investigate the relationship between structural empowerment, work engagement and organizational commitment. The result showed that the fresh nurses felt that the greater access to the workplace empowerment structures, a higher degree of the overall fit in the area of work-life occurred, in addition, employee-job fit resulted in the greater work engagement (less burnout), which ultimately led to greater organizational commitment. Reaching to support and formal power was strongly related to fit in the six areas of work life (workload, reward, control, community, fairness, value) which predicts the work engagement. Finally, the result reflected a strong relationship between organizational commitment and structural empowerment.

\section{Work Engagement and Employee Performance}

While Dajani (2015) conducted a study on (200) bank employees work in private and public operating in Cairo-Egypt. She evaluated the impact of leadership and organizational justice, compensations, work practice and procedures, training and development for being key determinants of employee engagement among employee working in the Egyptian banking sector. The researcher also examined the influence of the employee engagement on both organizational commitment and job performance. The result shows that the leadership style and organizational justice were of the great significance of employee engagement, moreover employee engagement ranked the top influence on work performance than on organizational commitment.

Guptaet al. (2015), conducted a study to determine the influence of job resources (co-worker support and supervisor support) on work engagement over 261 Indian academics in a higher education system, and how the interaction between job resources and perceived autonomy (psychological empowerment) influence the employee performance. Moreover, the study investigates the mediating role of work engagement in the relationship between job resources \& employee performance. The findings reveal that work engagement has a significant impact on employee performance, and work engagement mediates the relationship between supervisor support and service employee performance and the perceived autonomy moderate relationship between co-worker support and work engagement.

\section{Employee Empowerment, Work Engagement, and Employee Performance}

Social exchange theory(SET) is used to give a strong basis toclarify the relationship between the three variables: work engagement as mediator, empowerment and employee performance. According to(SET) employees feel required to repay the organization through showing engaged behaviors, they feel that their organization cares about them and feel valuable by receiving economics and socio-emotional resources from the organization, which resulted in affecting their level of performance in work as well as the whole organizational performance(Saks, 2006; Karatepe, 2013; Akhtar et al., 2016).

\section{Conclusion}

All the previous researchers, despite the difference in their environment and area of work, showed the massive importance of the empowerment in enhancing the level of engagement and improving employee outcomes. Those studies have widely used (SET) as a strong basis for interpreting connections between variables. The earliest researchers have highlighted the positive alliance of implementation of employee empowerment on employee performance through the mediating task of work engagement (Karatepe, 2013; Sattar et al., 2015; Akhtar et al., 2016), but those researchers have measured employee empowerment from organizational or structural perspective, thus, psychological dimensions of empowerment as important elements were neglected. But to have full examinations of empowerment concepts, the research should focus on the two type of employee empowerment jointly.

Also, most literature that studied the empowerment of hotel establishments conducted over the Western context, south Asian context (Pakistan, Malaysia, India, and Bangladesh) which required further empirical evidence in the different cultural context. Moreover, empowerment researches mainly focus on the front desk employee 
(frontline employee) role and ignoring the important role of sales and marketing workforce, which significantly generate business and create profit. The present paper suggests researchers to further examine the influence of the employee empowerment with its two types (structural and psychological) on sales \&marketing workforce performance in the presence of work engagement as mediating variable. Likewise, the studies which measure structural empowerment used Hayes scales (1994) with one dimension such as (Pelitet al., 2011; Karatepe, 2013; Sattar et al., 2015; Akhtar etal., 2016; Al-Ababneh et al., 2017), while the current paper suggests that researchers could measure the structural empowerment using six dimensions (information, support, opportunities, resources, formal and informal power) as described by the Kanter's theory.

Also, researchers called for more research on the enabling factors of applying electronic services (e.g. Karajeh $\&$ Maqableh, 2014; Maqableh \& Karajeh, 2014;Al-Dmour et al., 2015;Almajali\&Maqableh, 2015; Maqableh et al., 2015; Masa'deh, et al., 2015; Tarhini et al., 2015; 2016, 2017a, 2017b; Almajali \& Al-Dmour, 2016; Almajaliet al., 2016; Alenezi et al., 2017; Lamoure al., 2017; Khwaldeh et al., 2017; Yassien\& Mufleh,2017;Tarhini et al., 2018; Al-Dmour et al., 2019), hence, future research is vital to examine these enablers as to assist stakeholders on their decisions on reaching high levels of such services, and in turn empowering employees in an optimal way.

\section{References}

Abdissa, G., \& Fitwi, T. (2016). The impact of psychological empowerment on employees' job satisfaction: With reference to commercial bank of Ethiopia, Gedeo zone. Pyrex Journal of Business and Finance Management Research, 2(7), 65-80.

Abraiz, A., Tabassum, T. M., Raja, S., \& Jawad, M. (2012). Empowerment effects and employees job satisfaction. Academic Research International, 3(3), 392-400.

Abualoush, S., Bataineh, K., \& Alrowwad, A. (2018a). The role of knowledge management process and intellectual capital as intermediary variables between knowledge management infrastructure and organization performance. Interdisciplinary Journal of Information, Knowledge, and Management, 13, 279-309.

Abualoush, S. H., Obeidat, A. M., Tarhini, A., Masa'deh, R., \& Al-Badi, A. (2018b). The role of employees' empowerment as an intermediary variable between knowledge management and information systems on employees' performance. VINE Journal of Information and Knowledge Management Systems, 48(2), 217-237.

Ahadi, S., \& Suandi, T. (2014). Structural empowerment and organizational commitment: The mediating role of psychological empowerment in Malaysian research universities. Journal Asian Dev Stud, 3(1), 44-65.

Akhtar, A., Nawaz, M. K., Mahmood, Z., \& Shahid, M. S. (2016). Impact of high performance work practices on employees' performance in Pakistan: Examining the mediating role of employee engagement. Pakistan Journal of Commerce \& Social Sciences, 10(3), 708-724.

Al Azmi, N., Al-Lozi, M., Al-Zu'bi, Z., \& Dahiyat, S. (2012). Patients attitudes toward service quality and its impact on their satisfaction in physical therapy in KSA hospitals. European Journal of Social Sciences, 34(2), 300-314.

Al-Ababneh, M., Al-Sabi, S., Al-Shakhsheer, F., \& Masadeh, M. (2017). The influence of employee empowerment on employee job satisfaction in five-star hotels in Jordan. International Business Research, 10(3), 133-147.

Al-dalahmeh, M., Khalaf, R., \& Obeidat, B. (2018). The effect of employee engagement on organizational performance via the mediating role of job satisfaction: The case of IT employees in Jordanian banking sector. Modern Applied Science, 12(6), 17-43.

Al-Dmour, R, Obeidat, B., \& Almajali, D. (2015). The practice of HRIS applications in business organizations in Jordan: An empirical study. 4th Scientific \& Research Conference on New Trends in Business, Management and Social Sciences (COES\&RJ-TK15/1).

Al-Dmour, R., Al Haj Dawood, E., Al-Dmour, H., \& Masa'deh, R. (2019). The effect of customer lifestyle patterns on the use of mobile banking applications in Jordan. Int. J. Electronic Marketing and Retailing, Forthcoming.

Aldmour, R., Masa'deh, R., \& Obeidat, B. (2017). Factors influencing the adoption and implementation of HRIS applications: Are they similar. International Journal of Business Innovation and Research, 14(2), 139-167. 
Alenezi, H., Tarhini, A., Alalwan, A., \& Al-Qirim, N. (2017). Factors affecting the adoption of e-government in Kuwait: A qualitative study. Electronic Journal of e-Government, 15(2), 84-102.

AlHarrasi, J., \& AL-Lozi, M. (2015). The role of innovation management and technological innovation on organizational effectiveness. 4th Scientific \& Research Conference on New Trends in Business, Management and Social Sciences (COES\&RJ-TK15/1), Istanbul, Turkey.

AlHrassi, J., Al-Lozi, M., \& Irtaimeh, H. (2016). The impact of management innovation and technological innovation on organizational effectiveness: An empirical study from managerial staff perspective in Sultan Qaboos University. Journal of Social Sciences (COES\&RJ-JSS), 5(3), 309-339.

Alkandari, A., Masa'deh, R., \& Al-Lozi, M. (2017). Knowledge management and its role on organizational crisis management: A literature review. Journal of Social Sciences (COES\&RJ-JSS), 6(4), 833-850.

Almajali, D., \& Al-Dmour, R. (2016). The role of information technology in motivating students to accept e-learning adoption in universities: A case study in Jordanian universities. Journal of Business \& Management (COES\&RJ-JBM), 4(1), 36-46.

Almajali, D., \& Maqableh, M. (2015). Assessing the digital divide status of the Jordanian telecentre. International Journal of Communications, Network and System Sciences, 8(11), 428-439.

Almajali, D., Masa'deh, R., \& Al-Lozi, M. (2016). Determinants of the actual use of e-learning systems: An empirical study on Zarqa University in Jordan. Journal of Social Sciences (COES\&RJ-JSS), 5(2), 172-200.

Al-Syaidh, N., \& Al-Zu'bi, Z. (2014). Transformational leadership and its impact on the effectiveness of employees' behavior in the public and private Jordanian hospitals. Jordan Journal of Business Administration, 11(1), 23-57.

AL-Syaidh, N., Al- Lozi, M., \& AlHarrasi, J. (2016). Transformational leadership and its role on the effectiveness of employees' behavior: A theoretical study. Journal of Business \& Management (COES\&RJ-JBM), 4(1), 14-35.

Ambad, S. N. A., \& Bahron, A. (2012). Psychological empowerment: The influence on organizational commitment among employees in the construction sector. Journal of Global Business Management, 8(2), 73-81.

Ameer, M. H., Bhatti, S., \& Baig, S. (2014). Impact of employee empowerment on job satisfaction. Developing Country Studies, 4(9), 114-126.

Anitha, J. (2014). Determinants of employee engagement and their impact on employee performance. International Journal of Productivity and Performance Management, 63(3), 308-323.

Appelbaum, S. H., Karasek, R., Lapointe, F., \& Quelch, K. (2014). Employee empowerment: Factors affecting the consequent success or failure-part I. Industrial and Commercial Training, 47(1), 23-30.

Arunkumar, K., \& Renugadevi, M. R. (2013). Antecedents and consequences of employee engagement-A hypothetical approach. IOSR Journal of Business and Management (IOSR-JBM), 9(3), 52-57.

Ayupp, K., \& Chung, T. H. (2010). Empowerment: Hotel employees' perspective. Journal of Industrial Engineering and Management, 3(3), 561-575.

Azeem, H. K., \& Sayed, S. S. (2010). Influence of empowering employees on job satisfaction in youth care administrations at faculties of Assiut university (a comparative study). World Journal of Sport Sciences, 3, 1151-1159.

Blau, P. (1964). Exchange and power in social life. New York, NY: Wiley.

Cacioppe, R. (1998). Structured empowerment: An award-winning program at the Burswood resort hotel. Leadership \& Organization Development Journal, 19(5), 264-274.

Çağlar, E. S. (2012). Work engagement, empowerment and leadership styles: Analyses from cultural perspectives in hotel management. Journal of Global Strategic Management, 6(1), 17-31.

Çavuş, M. F., \& Demir, Y. (2010). The impacts of structural and psychological empowerment on Burnout: A research on staff nurses in Turkish state hospitals. Canadian Social Science, 6(4), 63-72.

Çavuş, Ş., Tokmak, C., \& Mambetova, N. (2015). Empowerment perceptions of employees in hotel enterprises. İşletme Araştırmaları Dergisi, 7(4), 6-23.

Conger, J. A., \& Kanungo, R. N. (1988). The empowerment process: Integrating theory and practice. Academy of 
Management Review, 13(3), 471-482.

Dajani, M. A. Z. (2015). The impact of employee engagement on job performance and organizational commitment in the Egyptian banking sector. Journal of Business and Management Sciences, 3(5), 138-147.

Darawsheh, S., ALshaar, A., \& AL-Lozi, M. (2016). The degree of heads of departments at the University of Dammam to practice transformational leadership style from the point of view of the faculty members. Journal of Social Sciences (COES\&RJ-JSS), 5(1), 56-79.

Elnaga, A. A., \& Imran, A. (2014). The impact of employee empowerment on job satisfaction: Theoretical study. American Journal of Research Communication, 2(1), 13-26.

Emerson, R. (1981). Social exchange. In M. Rosenberg And R. Turner (Eds.), Social Psychology: Sociological Perspectives (pp.3-24). New York, NY: Basic Books.

Gupta, M., Acharya, A., \& Gupta, R. (2015). Impact of work engagement on performance in Indian higher education system. Review of European Studies, 7(3), 192-201.

Guzel, T., Tükeltürk, Ş. A., \& Ozkul, O. (2008). Importance and effect of empowerment in hotel enterprises. Ege Academic Review, 8(2), 419-436.

Han, Y. (2015). A study on employee engagement program in full service hotel. A Professional Paper Submitted in Partial Fulfillment of The Requirements for The Master of Science Hotel Administration. University of Nevada, Las Vegas.

Hanaysha, J., \& Tahir, P. R. (2016). Examining the effects of employee empowerment, teamwork, and employee training on job satisfaction. Procedia-Social and Behavioral Sciences, 219, 272-282.

Hee, C. Y., Chng, H. C., Liew, P. M., \& Loke, L. B. (2014). Factors affect employees' performance in hotel industry. Doctoral Dissertation, UTAR.

Horwitz, S. K., \& Horwitz, I. B. (2017). The effects of organizational commitment and structural empowerment on patient safety culture: An analysis of a physician cohort. Journal of Health Organization and Management, 31(1), 10-27.

Iqbal, A., Ijaz, M., Latif, F., \& Mushtaq, H. (2015). Factors affecting the employee's performance: A case study of banking sector in Pakistan. European Journal of Business and Social Sciences, 4(08), 309-318.

Kahn, W. A. (1990). Psychological conditions of personal engagement and disengagement at work. Academy of Management Journal, 33(4), 692-724.

Kahya, E. (2007). The effects of job characteristics and working conditions on job performance. International Journal of Industrial Ergonomics, 37(6), 515-523.

Kanter, R. (1993). Men and women of the corporation. New York: Basic Book.

Karajeh, H., \& Maqableh, M. (2014). Security of cloud computing environment. The 23rd IBIMA Conference on Vision 2020: Sustainable Growth, Economic Development, and Global Competitiveness, USA, 2202-2215.

Karatepe, O. M. (2013). High-performance work practices and hotel employee performance: The mediation of work engagement. International Journal of Hospitality Management, 32, 132-140.

Kateb, M., Swies, R., Obeidat, B., \& Maqableh, M. (2015). An investigation on the critical factors of information system implementation in Jordanian information technology companies. European Journal of Business and Management, 7(36), 11-28.

Khalayleh, W., Masa'deh, R., \& Al-Lozi, M. (2017). Administrative empowerment and its role on the work teams Performance: A literature review. Journal of Social Sciences (COES\&RJ-JSS), 6(4), 851-868.

Khera, A. (2015). Impact of employee empowerment on job satisfaction: An empirical analysis of banks in Chandigarh, (India). International Research Journal of Human Resources and Social Sciences, 2(7), 30-39.

Khoshhal, A., \& Keshtegar, A. (2016). The effects of structural empowerment and organizational commitment on job satisfaction on the personnel at Islamic Azad university of Birjand. The Social Sciences, 11(7), 1234-1241.

Khwaldeh, S., Al-Hadid, I., Masa'deh, R., \& Alrowwad, A. (2017). The association between e-services web portals information quality and ICT competence in the Jordanian universities. Asian Social Science, 13(3), 156-169.

Kim, J. (2011). Exploring how employee empowerment impacts on hotel front desk operations. A Professional 
Paper Submitted in Partial Fulfillment of The Requirements for The Master of Science in Hotel Administration. University of Nevada, Lasvegas, USA.

Kok, P. C. (2011). A study of the impact of the empowerment on employee performance in the automotive industry in Malaysia. A Master's Project Submitted in Partial Fulfillment of The Requirements for the Degree of Master of Human Resource Management, Open University Malaysia.

Laschinger, H. K., Finegan, J., Shamian, J., \& Wilk, P. (2003). Workplace empowerment as a predictor of nurse burnout in restructured healthcare settings. Healthcare Quarterly, 1(3), 2-11.

Laschinger, H. K., Finegan, J., Shamian, J., \& Wilk, P. (2001). Impact of structural and psychological empowerment on job strain in nursing work settings: Expanding Kanter's model. Journal of Nursing Administration, 31(5), 260-272.

Laschinger, H. K., Finegan, J., Shamian, J., \& Wilk, P. (2004). A longitudinal analysis of the impact of workplace empowerment on work satisfaction. Journal of Organizational Behavior, 25(4), 527-545.

Lashley, C. (1995). Towards an understanding of employee empowerment in hospitality services. International Journal of Contemporary Hospitality Management, 7(1), 27-32.

Maqableh, M., \& Karajeh, H. (2014). Job scheduling for cloud computing using neural networks. Communications and Network, 6(3), 191-200.

Maqableh, M., Rajab, L., Quteshat, W., Khatib, T., \& Karajeh, H. (2015). The impact of social media networks websites usage on students' academic performance. Communications and Network, 7(4), 159-171.

Masa'deh, R., Alrowwad, A., Alkhalafat, F., Obeidat, O., \& Abualoush, S. (2018). The role of corporate social responsibility in enhancing firm performance from the perspective of IT employees in Jordanian banking sector: The mediating effect of transformational leadership. Modern Applied Science, 12(7), 1-26.

Masa'deh, R., Hunaiti, Z., \& Bani Yaseen, A. (2008). An integrative model linking IT-business strategic alignment and firm performance: The mediating role of pursuing innovation and knowledge management strategies. Communications of the International Business Information Management Association (IBIMA) Journal.

Masa'deh, R., Obeidat, B., Al-Dmour, R., \& Tarhini, A. (2015). Knowledge management strategies as intermediary variables between IT-business strategic alignment and firm performance. European Scientific Journal, 11(7), 344-368.

Maslach, C., Schaufeli, W. B., \& Leiter, M. P. (2001). Job burnout. Annual Review of Psychology, 52(1), 397-422.

Mehrabani, S. E., \& Shajari, M. (2013). Relationship between employee empowerment and employee effectiveness. Service Science and Management Research, 2(4), 60-68.

Melhem, Y. (2004). Significant conditions in employees empowerment: The case of Jordanian four star hotels. In the Fifth Annual Arabian Conference in Management, Egypt, pp. 332-376.

Mikkawi, B., \& Al-Lozi, M. (2017). The impact of knowledge management infrastructure on academic staff effectiveness: An empirical study at The University of Jordan. Jordan Journal of Business Administration, 13(1), 95-127.

Mohammadian, M., \& Amirkabiri, A. (2014). A study of the relation between empowerment, job satisfaction, job stress and organizational commitment: A case study of the central office of Petro Pars company. Indian J. Sci. Res, 7(1), 855-869.

Muda, I., Rafiki, A., \& Harahap, M. R. (2014). Factors influencing employees' performance: A study on the Islamic banks in Indonesia. International Journal of Business and Social Science, 5(2), 73-80.

Nawaz, M. S., Hassan, M., Hassan, S., Shaukat, S., \& Asadullah, M. A. (2014). Impact of employee training and empowerment on employee creativity through employee engagement: Empirical evidence from manufacturing sector of Pakistan. Middle-East Journal of Scientific Research, 19(4), 593-601.

Nawrin, R. (2016). Impact of psychological empowerment on employees' work and organization engagement: A study in the manufacturing sectors, Bangladesh. Mediterranean Journal of Social Sciences, 7(5), 389-395.

Obeidat, B., El-Rimawi, S., Maqableh, M., \& Al-Jarrah, I. (2013). Evaluating the profitability of the Islamic banks in Jordan. European Journal of Economics, Finance and Administrative Sciences, 56, 27-36. 
Obeidat, B., Sweis, R., Zyod, D., \& Alshurideh, M. (2012). The effect of perceived service quality on customer loyalty in internet service providers in Jordan. Journal of Management Research, 4(4), 224-242.

Obeidat, B., Tarhini, A., \& Aqqad, N. (2017). The impact of intellectual capital on innovation via the mediating role of knowledge management: A structural equation modeling approach. International Journal of Knowledge Management Studies, 8(3/4), 273-298.

O'Brien, J. L. (2010). Structural empowerment, psychological empowerment and burnout in registered staff nurses working in outpatient dialysis centers. Doctoral Dissertation, Rutgers University-Graduate School-Newark.

Orgambídez-Ramos, A., \& Borrego-Alés, Y. (2014). Empowering employees: Structural empowerment as antecedent of job satisfaction in university settings. Psychological Thought, 7(1), 28-36.

Oxford dictionary (2018). Oxford University Press. Retrieved January 2018 from https://En.Oxforddictionaries.Com/Definition/Empowerment

Pelit, E. Ozturk, Y., \& Arslanturk, Y. (2011). The effects of employee empowerment on employee job satisfaction a study on hotels in Turkey. International Journal of Contemporary Hospitality Management, 23(6), 784-802.

Rajalingam, Y., Jauhar, J., \& Bashawir, A. G. (2015). A study on the impact of empowerment on employee performance: The mediating role of appraisal. International Journal of Liberal Arts and Social Science, 3(1), 92-104.

Rana, S., \& Singh, V. (2016). Employee empowerment and job satisfaction: An empirical study in IT industry. IOSR Journal of Humanities and Social Science, 21(10), 23-29.

Regan, L. C., \& Rodriguez, L. (2011). Nurse empowerment from A middle-management perspective: Nurse managers' and assistant nurse managers' workplace empowerment views. The Permanente Journal, 15(1), 101-107.

Rehman, R., Arfeen, M. N., \& Sabir, S. (2015). The impact of health professionals empowerment as a shared responsibility to enhance job satisfaction within health sector of Pakistan. International Journal of Management Sciences and Business Research, 4(8), 46-54.

Rizwan, M., Waseem, A., \& Bukhari, S. A. (2014). Antecedents of job stress and its impact on job performance and job satisfaction. International Journal of Learning and Development, 4(2), 187-203.

Saks, A. M. (2006). Antecedents and consequences of employee engagement. Journal of Managerial Psychology, 21(7), 600-619.

Sarmiento, T. P., Laschinger, H. K., \& Iwasiw, C. (2004). Nurse educators' workplace empowerment, burnout, and job satisfaction: Testing Kanter's theory. Journal of Advanced Nursing, 46(2), 134-143.

Sattar, T., Ahmad, K., \& Hassan, S. M. (2015). Role of human resource practices in employee performance and job satisfaction with mediating effect of employee engagement. Pakistan Economic and Social Review, 53(1), 81-96.

Scarnati, J. T., \& Scarnati, B. J. (2002). Empowerment: The key to quality. The TQM Magazine, 14(2), 110-119.

Schaufeli, W. B., Salanova, M., González-Romá, V., \& Bakker, A. B. (2002). The measurement of engagement and burnout: A two sample confirmatory factor analytic approach. Journal of Happiness Studies, 3(1), 71-92.

Shahril, A. M., Aziz, Y. A., Othman, M., \& Bojei, J. (2013). The relationship between service guarantees, empowerment, employee satisfaction and service quality in four and five star hotels in Malaysia. Journal of Economics, Business and Management, 1(1), 90-93.

Shannak, R., \& Obeidat, B. (2012). Culture and the implementation process of strategic decisions in Jordan. Journal of Management Research, 4(4), 257-281.

Songan, P., Pillai, N. R., \& Bandar, N. F. A. (2016). Empowerment of front-line employees in the hospitality industry: A survey of three five-star hotels in Kuala Lumpur, Malaysia. Conference Paper. Malaysia, pp. 721-729.

Spreitzer, G. M. (1995). Psychological empowerment in the workplace: Dimensions, measurement and validation. Academy of Management Journal, 38(5), 1442-1465. 
Stander, M. W., \& Rothmann, S. (2010). Psychological empowerment, job insecurity and employee engagement. SA Journal of Industrial Psychology, 36(1), 1-8.

Suliman, A. M. (2001). Work performance: Is it one thing or many things? The multidimensionality of performance in a Middle Eastern context. International Journal of Human Resource Management, 12(6), 1049-1061.

Sun, X. (2016). Psychological empowerment on job performance: Mediating effect of job satisfaction. Psychology, 7(04), 584-590.

Tajuddin, S. S. B. (2013). A study on the factors of employee empowerment on work performance in the manufacturing industry. Report Submitted in Partial Fulfillment of the Requirements for The Award of The Degree of Bachelor of Industrial Technology Management with Hons, University Malaysia Pahang, Malaysia.

Tarhini, A., Alalwan, A., Al-Qirim, N., \& Algharabat, R. (2018). An analysis of the factors influencing the adoption of online shopping. International Journal of Technology Diffusion (IJTD), 9(3), 68-87.

Tarhini, A., Al-Badi, A., Almajali, M., \& Alrabayaah, S. (2017a). Factors influencing employees' intention to use cloud computing. Journal of Management and Strategy, 8(2), 47.

Tarhini, A., Al-Busaidi, K., Bany Mohammed, A., \& Maqableh, M. (2017b). Factors influencing students' adoption of e-learning: A structural equation modeling approach. Journal of International Education in Business, 10(2), 164-182.

Tarhini, A., Bany Mohammed, A., \& Maqableh, M. (2016). Modeling factors affecting student's usage behaviour of e-learning systems in Lebanon. International Journal of Business and Management, 11(2), 299.

Tarhini, A., Mgbemena, C., \& Trab, MSA. (2015). User adoption of online banking in Nigeria: A qualitative study. Journal of Internet Banking and Commerce, 20(3), 1-8.

Tetik, N. (2016). The effects of psychological empowerment on job satisfaction and job performance of tourist guides. International Journal of Academic Research in Business and Social Sciences, 6(2), 221-239.

Thomas, K. W., \& Velthouse, B. A. (1990). Cognitive elements of empowerment: An "interpretive" model of intrinsic task motivation. Academy of Management: The Academy of Management Review, 15(4), 666-681.

Ugwu, F. O., Onyishi, I. E., \& Rodríguez-Sánchez, A. M. (2014). Linking organizational trust with employee engagement: The role of psychological empowerment. Personnel Review, 43(3), 377-400.

Ukil, M. I. (2016). The impact of employee empowerment on employee satisfaction and service quality: Empirical evidence from financial enterprises in Bangladesh. Business: Theory and Practice, 17(2), 178-189.

Vroom, V. (N.D.). Expectancy theory of motivation-victor vroom. Leadership-Central.Com. Retrieved 2018, from http://www.Leadership-Central.Com/Expectancy-Theory-Of-Motivation.Html\#Axzz343jodfb

Yaghoobi, N. M., Moloudi, J., \& Azadikhah, O. (2011). The relationship between empowerment and human resource productivity in organization. Journal of Basic and Applied, 1(10), 1603-1610.

Yassien, E., \& Mufleh, M. (2017). The impact of ERP system's usability on enterprise resource planning project implementation success via the mediating role of user satisfaction. Journal of Management Research, 9(3), 49-71.

Yilmaz, O. D. (2015). Revisiting the impact of perceived empowerment on job performance: Results from front-line employees. Turizam, 19(1), 34-46.

Zainol, S. S., \& Binti Othman, M. S. (2016). Determinants of employee engagement in hotel industry in Malaysia. A theoretical mode. International Journal of Academic Research in Accounting, Finance and Management Sciences, 6(3), 1-9.

\section{Copyrights}

Copyright for this article is retained by the author(s), with first publication rights granted to the journal.

This is an open-access article distributed under the terms and conditions of the Creative Commons Attribution license (http://creativecommons.org/licenses/by/4.0/) 